\title{
Denitrification in the water column of the central Baltic Sea
}

\author{
Tage Dalsgaard ${ }^{\mathrm{a}, \mathrm{b}, *}$, Loreto De Brabandere $^{\mathrm{c}}$, Per O.J. Hall ${ }^{\mathrm{d}}$ \\ ${ }^{a}$ Department of Bioscience, Aarhus University, Vejlsøvej 25, DK-8600 Silkeborg, Denmark \\ ${ }^{\mathrm{b}}$ Arctic Research Centre, Aarhus University, C. F. Møllers Allé 8, DK-8000 Aarhus C, Denmark \\ ${ }^{\mathrm{c}}$ Nordic Center for Earth Evolution (NordCEE), Institute of Biology, University of Southern Denmark, Campusvej 55, \\ 5230 Odense M, Denmark \\ ${ }^{\mathrm{d}}$ Department of Chemistry and Molecular Biology, Marine Chemistry, University of Gothenburg, SE-41296 Gothenburg, Sweden
}

Received 9 July 2012; accepted in revised form 28 December 2012; available online 4 January 2013

\begin{abstract}
Removal of fixed nitrogen in the water column of the eastern Gotland Basin, central Baltic Sea, was studied during two cruises in September 2008 and August 2010. The water column was stratified with anoxic sulfidic bottom water meeting oxic nitrate containing water at the oxic-anoxic interface. Anammox was never detected whereas denitrification was found in all incubations from anoxic depths and occurred immediately below the oxic-anoxic interface. Sulfide $\left(\mathrm{H}_{2} \mathrm{~S}+\mathrm{HS}^{-}+\mathrm{S}^{2-}\right)$ was in most cases the only electron donor for denitrification but, in contrast to previous findings, denitrification was in some situations driven by organic matter alone. Nitrous oxide $\left(\mathrm{N}_{2} \mathrm{O}\right)$ became an increasingly important product of denitrification with increasing sulfide concentration and was $>80 \%$ of the total $\mathrm{N}$ gas formation at $10 \mu \mathrm{M}$ sulfide. The potential rates of denitrification measured in incubations at elevated $\mathrm{NO}_{3}^{-}$or sulfide concentrations were converted to in situ rates using the measured water column concentrations of $\mathrm{NO}_{3}^{-}$and sulfide and the actual measured relations between $\mathrm{NO}_{3}^{-}$and sulfide concentrations and denitrification rates. In situ denitrification ranged from 0.24 to $15.9 \mathrm{nM} \mathrm{N}_{2} \mathrm{~h}^{-1}$. Assuming that these rates were valid throughout the anoxic $\mathrm{NO}_{3}^{-}$containing zone, depth integrated in situ denitrification rates of $0.06-2.11 \mathrm{mmol} \mathrm{N} \mathrm{m}^{-2} \mathrm{~d}^{-1}$ were estimated. The thickness of this zone was generally 3-6 m, which is probably what can be maintained through regular turbulent mixing induced by internal waves at the oxic-anoxic interface. However, layers of up to $55 \mathrm{~m}$ thickness with low $\mathrm{O}_{2}$ water $(<10 \mu \mathrm{M})$ were observed which was probably the result of larger scale mixing. In such a layer nitrification may produce $\mathrm{NO}_{3}^{-}$ and once the $\mathrm{O}_{2}$ has been depleted denitrification will follow resulting in enormous rates per unit area. Even with an active denitrification layer of 3-6 m thickness the pelagic denitrification per unit area clearly exceeded sediment denitrification rates elsewhere in the Baltic Sea. When extrapolated to the entire Baltic Proper (BP) denitrification in the water column was in the

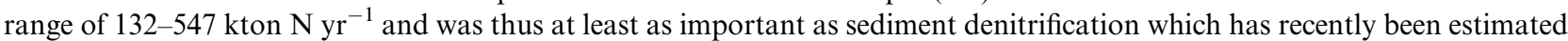

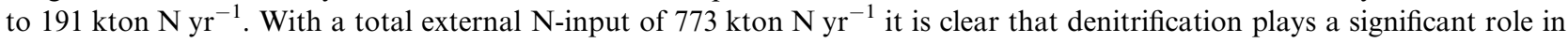
the N-budget of the BP.
\end{abstract}

(C) 2013 Elsevier Ltd. All rights reserved.

\section{INTRODUCTION}

The Baltic Sea is a large brackish sea with limited exchange of water through the straits between Denmark

\footnotetext{
* Corresponding author at: Department of Bioscience, Aarhus University, Vejlsøvej 25, DK-8600 Silkeborg, Denmark.

E-mail addresses: tda@dmu.dk (T. Dalsgaard), loreto.sdu@gmail.com (L. De Brabandere), perhall@chem.gu.se (P.O.J. Hall).
}

and Sweden (Reissmann et al., 2009). The average depth is $52 \mathrm{~m}$ (Hietanen et al., 2012) but a number of significantly deeper basins exist and one of these is the eastern Gotland Basin (EGB) with a maximum depth of ca. $250 \mathrm{~m}$, where this study was carried out. With irregular intervals of several years major inflow events take place and saline water from the North Sea flows over the sills and fills up the deeper basins and the last major inflow event was in January 2003 (Matthäus et al., 2008). During stagnation periods be- 
tween major inflow events the deeper basins are anoxic and sulfidic from the sediment up to the pycnocline. When major inflow events occur, however, this water is replaced with oxygenated water. This oxygenated and more saline water is separated from the surface waters by a pycnocline through which only little transport occurs (Reissmann et al., 2009), and the basins below the pycnocline gradually return to the anoxic state through oxygen consumption in water column and sediment. After anoxia is established there will be a period of time before sulfide accumulates to high concentrations, as observed after the 2003 inflow (Hannig et al., 2007).

The limited water exchange and the relatively large watershed makes the Baltic Sea vulnerable to eutrophication and increasing nutrient loads over several decades have increased the area, volume and frequency of oxygen deficiency not only in the deeper basins but also in the coastal areas (Nausch et al., 1999; Conley et al., 2011; Voss et al., 2011). The nitrogen part of the eutrophication is to some degree counteracted by removal of fixed nitrogen in the anoxic parts of sediments and water columns (Voss et al., 2005). This removal is known to be mediated by denitrification and/or anammox, which occur only at very low or zero oxygen concentrations (Hulth et al., 2005; Kuypers et al., 2005; Jensen et al., 2008; Thamdrup and Dalsgaard, 2008). Both processes require $\mathrm{NO}_{3}^{-}$or $\mathrm{NO}_{2}^{-}$(hereafter collectively called $\mathrm{NO}_{x}^{-}$) as substrate, which may be supplied from either nitrification or from land and in either case $\mathrm{NO}_{x}^{-}$will be present in oxic waters. Denitrification and anammox will thus occur if $\mathrm{NO}_{x}^{-}$is transported from these oxic waters into low oxygen environments or if $\mathrm{NO}_{x}^{-}$containing water or sediment becomes depleted of oxygen. This may be the case at oxic-anoxic interfaces in sediments (Risgaard-Petersen et al., 2005) or at the oxycline where anoxic bottom waters meet oxic surface waters (Brettar and Rheinheimer, 1991; Jensen et al., 2009; Lam and Kuypers, 2011). Furthermore, the electron donor for anammox, $\mathrm{NH}_{4}^{+}$, is generally removed by nitrification in water columns even at very low oxygen concentrations (Lam et al., 2007) and will only reach measurable concentrations in the absence of oxygen. Therefore, if anammox would be active in the Baltic Sea water column it must occur in be the uppermost part of the anoxic zone, where $\mathrm{NO}_{x}^{-}$may be mixed down from above, and $\mathrm{NH}_{4}^{+}$is not being removed by nitrifiers. However, if sulfide accumulates this may inhibit anammox (Dalsgaard et al., 2003; Jensen et al., 2008). The electron donor for denitrification in the Baltic Sea water column has mainly been found to be sulfide (Brettar and Rheinheimer, 1991; Hietanen et al., 2012) and only once organic matter was suggested also to play a role (Rönner and Sörensson, 1985). However, in that study the incubation time was 1-4 weeks and the result may not represent the in situ conditions.

In this study we focus on the removal of fixed nitrogen around the oxycline in the EGB at the interface between sulfidic anoxic bottom water and oxic surface waters. Denitrification has been repeatedly found here previously (Rönner and Sörensson, 1985; Brettar and Rheinheimer, 1991; Hannig et al., 2007; Hietanen et al., 2012), whereas the presence of anammox activity has only been reported once
(Hannig et al., 2007). It was argued that the anammox activity was promoted by the development of an anoxic $\mathrm{NO}_{x}^{-}$containing sulfide free zone, during the transition from oxic to anoxic and sulfidic conditions after a major inflow event. In the presence of sulfide, denitrification with sulfide as electron donor is likely to be active and outcompete anammox bacteria which may be inhibited by the presence of sulfide (Dalsgaard et al., 2003; Jensen et al., 2008). Such sulfide free and $\mathrm{NO}_{x}^{-}$containing zones may potentially also develop after smaller mixing events but it is not known whether this may lead to anammox activity. The earlier studies were done before the discovery of anammox and with the acetylene blockage technique (Rönner and Sörensson, 1985; Brettar and Rheinheimer, 1991, 1992) and, therefore, anammox was not investigated. Apart from the Hannig et al. (2007) study only one study in the Baltic Sea has applied the isotope technique that would reveal anammox (Hietanen et al., 2012). However, neither anammox nor denitrification was detected in the zone immediately below the oxic-anoxic interface. In the present study we applied the isotope pairing technique for measuring anammox and denitrification in a way that minimized the potential errors of the technique, yielding more realistic estimates of nitrogen removal. We specifically targeted the zone right below the oxic-anoxic interface where these processes may be expected to occur. As both anammox and denitrification are known to be inhibited by oxygen, and because sulfide, which may be electron donor for denitrification, will disappear if oxygen is present we applied this technique in a way that would minimize the oxygen contamination. This was not done in some of the previous Baltic Sea studies and it is especially critical in the low sulfide environment right below the oxic-anoxic interface, whereas further down the higher sulfide concentrations may help remove oxygen contamination and facilitate the anaerobic processes. Furthermore, we investigated the electron donor for denitrification and the kinetics of $\mathrm{NO}_{x}^{-}$- and sulfide uptake by denitrification which allowed us to rescale potential process rates into in situ rates.

\section{MATERIALS AND METHODS}

\subsection{Sampling}

Sampling was performed in the western part of the EGB during two cruises with the University of Gothenburg's RV Skagerak in September 2008 and August 2010 (Fig. 1). Water samples were retrieved using a rosette sampler with 12 Niskin bottles of $10 \mathrm{~L}$ each and a Sea-Bird CTD with a SBE 43 oxygen sensor.

The interface between oxic and anoxic waters was identified as the depth where the signal of the oxygen sensor started to increase when the sensor was pulled slowly upwards after a period of 10-20 min in the anoxic bottom waters. During this stay in the anoxic waters the signal for zero oxygen slowly decreased as the oxygen reservoir in the plastic housing and electrolyte of the oxygen sensor got depleted. Once the signal was stable it was easy to identify the rise in signal when oxygenated water was encountered. Water column profiles of $\mathrm{NO}_{3}^{-}, \mathrm{NO}_{2}^{-}, \mathrm{NH}_{4}^{+}$, sulfide, 

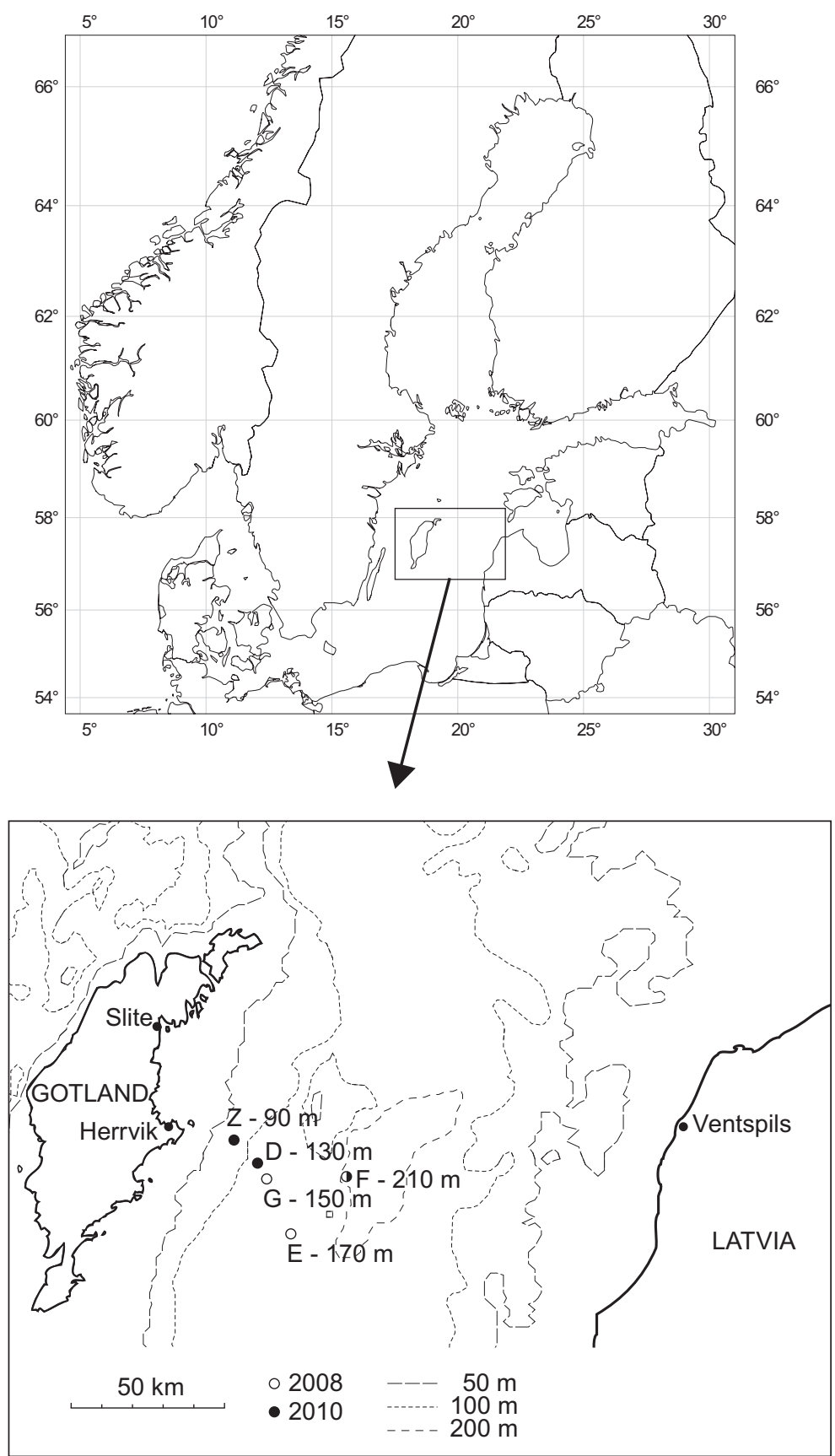

Fig. 1. Locations of the sampling stations in the Eastern Gotland Basin in the Baltic Sea. Sampling year and bottom depth of each station are indicated. Bathymetry shown as contours.

and $\mathrm{PO}_{4}^{3-}$ were measured on 12 discrete samples from the Niskin bottles at approximately $5 \mathrm{~m}$ intervals in 2008 and $1 \mathrm{~m}$ intervals in 2010 around the oxic-anoxic interface. Water for incubations was sampled from three depths in 2008, which was approximately at the oxic-anoxic interface and 5 and $10 \mathrm{~m}$ below, and from one depth in 2010, which was $3-3.5 \mathrm{~m}$ below the interface.

\subsection{Incubations}

Water for incubations was taken from the Niskin bottles immediately when the rosette was on deck and always be- fore any other sampling from the same bottles. Water flowed through a piece of Tygon tubing into the bottom of a $500 \mathrm{ml}$ glass bottle and was allowed to overflow for three volume changes. The glass bottle was immediately closed with a butyl rubber stopper with no bubbles or headspace, and brought to the lab where it was kept within $1^{\circ} \mathrm{C}$ of in situ temperature. Time between sampling from the Niskin bottles and start of the incubations was less than $3 \mathrm{~h}$.

The incubations were designed to quantify and identify the processes removing fixed nitrogen (anammox and denitrification) applying the ${ }^{15} \mathrm{~N}$-tracer technique as described earlier (Dalsgaard et al., 2003; Thamdrup et al., 2006). 
Briefly, the bottle of water was amended with ${ }^{15} \mathrm{~N}$-tracer, gassed with helium for $15 \mathrm{~min}$ and then dispensed into 10 glass vials with a butyl rubber septum (12 ml Labco Exetainers). At all stations, years, and depths an incubation with ${ }^{15} \mathrm{NH}_{4}^{+}+{ }^{14} \mathrm{NO}_{3}^{-}(10 \mu \mathrm{M}$ each $)$ was performed to check for anammox activity. The ${ }^{15} \mathrm{NO}_{3}^{-}$incubations were carried out differently in the two years. In 2008 two parallel incubations from each depth with $10 \mu \mathrm{M}^{15} \mathrm{NO}_{3}^{-}\left({ }^{15} \mathrm{~N}\right.$ in $\mathrm{NO}_{3}^{-}$pool was $67-98 \%$ ) were performed, one with amendment of 2 $4 \mu \mathrm{M} \mathrm{Na}{ }_{2} \mathrm{~S}$ and one with no $\mathrm{Na}_{2} \mathrm{~S}$ amendment. In 2010 the ${ }^{15} \mathrm{NO}_{3}^{-}$incubations were performed as two concentration series at one depth at each station, varying the $\mathrm{NO}_{3}^{-}$ concentration in one series and the sulfide concentration in the other $\left({ }^{15} \mathrm{~N}\right.$ in $\mathrm{NO}_{3}^{-}$pool was $\left.17-99 \%\right)$. In the $\mathrm{NO}_{3}^{-}$ concentration series the final concentrations of ${ }^{15} \mathrm{NO}_{3}^{-}$were $1,2,5$, and $10 \mu \mathrm{M}$. In the sulfide concentration series ${ }^{15} \mathrm{NO}_{3}^{-}$was added to a final concentration of $1 \mu \mathrm{M}$ in all incubations and $\mathrm{Na}_{2} \mathrm{~S}$ was added to increase the ambient $\mathrm{H}_{2} \mathrm{~S}$ concentration by $0,1,5$, and $10 \mu \mathrm{M}$. It was assumed that the effect of $\mathrm{Na}_{2} \mathrm{~S}$ amendment on $\mathrm{pH}$ was negligible given the total alkalinity of $1700-1800 \mu \mathrm{mol} / \mathrm{kg}$ (Ulfsbo et al., 2011). In 2010 the empty Exetainers were filled with $\mathrm{He}$ 2 weeks before the cruise to lower the $\mathrm{O}_{2}$ content of the septum. Furthermore, incubations were done with a $2 \mathrm{ml}$ helium headspace in the Exetainers to lower the possible $\mathrm{O}_{2}$ contamination in the incubation even further (De Brabandere et al., 2012). This was created by withdrawing $2 \mathrm{ml}$ sample while simultaneously allowing helium to flow in through a second needle, and after shaking the Exetainers vigorously the headspace was flushed with helium and shaken again before incubation. For both years the Exetainers were sacrificed in pairs over the ca. $24 \mathrm{~h}$ incubation period by replacing $5 \mathrm{ml}$ of sample with helium, as described above, and finally adding $100 \mu \mathrm{l}$ of a $50 \%$ (w/v) $\mathrm{ZnCl}_{2}$ with a needle through the septum to stop microbial activity. Part of the withdrawn water sample was analyzed for $\mathrm{NO}_{2}^{-}$ immediately, part was injected into a $20 \%$ zinc acetate solution for sulfide analysis and part was filtered (Whatman $\mathrm{GF} / \mathrm{F}$ ) and frozen for later analysis of $\mathrm{NO}_{3}^{-}$. The Exetainer was stored upside down for later analysis of the isotopic composition of $\mathrm{N}_{2}$.

Part of the total sulfide was present as $\mathrm{H}_{2} \mathrm{~S}$, which may be removed by gassing of the water before incubation and may escape into the headspace of the Exetainers in the 2010 incubations. The loss of sulfide due to He gassing was found in 14 incubations in 2008 never to exceed $10 \%$ and was on average $2.5 \%$ of the initial sulfide concentration. The loss of sulfide to the headspace of Exetainers in 2010 was calculated according to Millero (1986). With an assumed $\mathrm{pH}$ value of 7.1 (Ulfsbo et al., 2011), temperature of $7{ }^{\circ} \mathrm{C}$, and a salinity of 10 approximately $2.5 \%$ of the total sulfide in the $12 \mathrm{ml}$ Exetainer would be present as $\mathrm{H}_{2} \mathrm{~S}$ in the headspace. This loss of sulfide due to gassing or introduction of a headspace was judged negligible and was not corrected for.

\subsection{Analytical}

Nitrogen isotopes in $\mathrm{N}_{2}$ were analyzed by GC-IRMS with a custom-made GC setup coupled to a Thermo Delta
V Plus mass spectrometer (Thermo, Bremen, Germany), and the excess ${ }^{14} \mathrm{~N}^{15} \mathrm{~N}$ and ${ }^{15} \mathrm{~N}^{15} \mathrm{~N}$ was quantified as described by Thamdrup and Dalsgaard (2000). The GC system consisted of a manual injection port connected to, in series, a combined ascarite $/ \mathrm{Mg}\left(\mathrm{ClO}_{4}\right)_{2}$ trap for $\mathrm{CO}_{2}$ and $\mathrm{H}_{2} \mathrm{O}$, a Porapak R chromatographic column, a $600{ }^{\circ} \mathrm{C}$ reduced copper column removing $\mathrm{O}_{2}$, and a second $\mathrm{Mg}\left(\mathrm{ClO}_{4}\right)_{2}$ trap. The GC system was coupled to the IRMS via a Thermo ConFlo-III interface. ${ }^{15} \mathrm{~N}$ labeled $\mathrm{N}_{2} \mathrm{O}$ was also quantified with the system after separation from $\mathrm{N}_{2}$ on the GC column and quantitative reduction to $\mathrm{N}_{2}$ on the hot copper column. Due to the higher solubility of $\mathrm{N}_{2} \mathrm{O}$ than $\mathrm{N}_{2}$ in water, and the fact that these gasses were extracted from the sample with a headspace technique, a lower fraction of the $\mathrm{N}_{2} \mathrm{O}$ than the $\mathrm{N}_{2}$ present in the sample entered the mass spectrometer and total sensitivity for $\mathrm{N}_{2} \mathrm{O}$ was about half that of $\mathrm{N}_{2}$. Nitrite was analyzed colorimetrically according to Grasshoff et al. (1983), $\mathrm{NO}_{x}^{-}$ $\left(\mathrm{NO}_{3}^{-}+\mathrm{NO}_{2}^{-}\right)$was quantified as $\mathrm{NO}$ after reduction in hot $\mathrm{VCl}_{3}$ (Braman and Hendrix, 1989), and sulfide was quantified according to Cline (1969) after trapping in a $20 \%(\mathrm{w} / \mathrm{v})$ zinc acetate solution.

\subsection{Calculations}

Production rates of $\mathrm{N}_{2}$ from anammox in the ${ }^{15} \mathrm{NH}_{4}^{+}$ incubations and from denitrification in the ${ }^{15} \mathrm{NO}_{3}^{-}$incubations were calculated according to Eqs. (1) and (2), respectively (Thamdrup and Dalsgaard, 2002):

$\mathrm{N}_{2 \text { anammox }}={ }^{14} \mathrm{~N}^{15} \mathrm{~N}_{\mathrm{xs}} / F_{\text {ammonium }}$
$\mathrm{N}_{2 \text { denitrification }}={ }^{15} \mathrm{~N}^{15} \mathrm{~N}_{\mathrm{xs}} /\left(F_{\text {nitrate }}\right)^{2}$

where $\mathrm{N}_{2}$ anammox is the production of $\mathrm{N}_{2}$ by anammox in the ${ }^{15} \mathrm{NH}_{4}^{+}$incubations, $\mathrm{N}_{2}$ denitrification is the production of $\mathrm{N}_{2}$ by denitrification in the ${ }^{15} \mathrm{NO}_{3}^{-}$incubations, $F_{\text {ammo- }}$ nium is the mole fraction of ${ }^{15} \mathrm{~N}$ in the $\mathrm{NH}_{4}^{+}$pool in the ${ }^{15} \mathrm{NH}_{4}^{+}$incubations, $F_{\text {nitrate }}$ is the mole fraction of ${ }^{15} \mathrm{~N}$ in the $\mathrm{NO}_{3}^{-}$pool in the ${ }^{15} \mathrm{NO}_{3}^{-}$incubations, and ${ }^{14} \mathrm{~N}^{15} \mathrm{~N}_{\mathrm{xs}}$ and ${ }^{15} \mathrm{~N}^{15} \mathrm{~N}_{\mathrm{xs}}$ are the production rates of excess ${ }^{14} \mathrm{~N}^{15} \mathrm{~N}$ and ${ }^{15} \mathrm{~N}^{15} \mathrm{~N}$ over their natural abundance. Rates of ${ }^{14} \mathrm{~N}^{15} \mathrm{~N}_{\mathrm{xs}}$ and ${ }^{15} \mathrm{~N}^{15} \mathrm{~N}_{\mathrm{xs}}$ production were estimated as the slope of the linear regression of their respective concentrations versus time during the incubations. Denitrification and anammox were considered significant if both ${ }^{14} \mathrm{~N}^{15} \mathrm{~N}$ and ${ }^{15} \mathrm{~N}^{15} \mathrm{~N}$ production were significantly $>0$ ( $t$-test, $p<0.05)$. Nitrous oxide production in the ${ }^{15} \mathrm{NO}_{3}^{-}$incubations was calculated similar to the $\mathrm{N}_{2}$ production by denitrification above by substituting ${ }^{15} \mathrm{~N}^{15} \mathrm{~N}_{\mathrm{xs}}$ in Eq. (2) by ${ }^{15} \mathrm{~N}^{15} \mathrm{NO}_{\mathrm{xs}}$.

The thickness of the water layers where denitrification may occur was estimated as the distance from the oxicanoxic interface down to the layer where $\mathrm{NO}_{x}^{-}$reached zero. The average concentrations of $\mathrm{NO}_{x}^{-}$and sulfide for each sampling interval within this zone were estimated and, together with the actual measured relations between $\mathrm{NO}_{x}^{-}$and sulfide concentrations and denitrification rates, used to convert the denitrification rates measured at elevated $\mathrm{NO}_{x}^{-}$and sulfide concentrations to in situ denitrification 
rates. The eddy diffusion coefficient required to sustain the measured rates of denitrification was calculated as:

$K_{z}=-F_{z} /(\mathrm{d} C / \mathrm{d} z)$

where $F_{z}$ is the $\mathrm{NO}_{x}^{-}$flux needed to sustain the measured denitrification rate, $\mathrm{d} C / \mathrm{d} z$ is the $\mathrm{NO}_{x}^{-}$concentration gradient and $K_{z}$ is the vertical eddy diffusivity (Jensen et al., 2009). The $\mathrm{NO}_{x}^{-}$gradient was estimated from two discrete measurements immediately above the oxic-anoxic interface to represent the driving force of $\mathrm{NO}_{x}^{-}$into the denitrification zone.

\section{RESULTS}

\section{1. ${ }^{15} \mathrm{~N}$ incubations}

Production of ${ }^{14} \mathrm{~N}^{15} \mathrm{~N}$ in the ${ }^{15} \mathrm{NH}_{4}^{+}$incubations was never recorded, indicating that anammox was not active at any depth or station in neither 2008 nor 2010. On the other hand ${ }^{15} \mathrm{~N}^{15} \mathrm{~N}$ production was recorded in the ${ }^{15} \mathrm{NO}_{3}^{-}$ incubations at many depths and stations in both years leading to significant rates of denitrification.

In 2008, when denitrification was quantified at three depths at each station, rates at in situ sulfide concentrations increased clearly with depth (Fig. 2). At the upper sampling depth denitrification was not detectable at in situ sulfide concentrations but measurable at station $\mathrm{F}$ when $\mathrm{Na}_{2} \mathrm{~S}$ was added. Deeper down additions of $\mathrm{Na}_{2} \mathrm{~S}$ had a marked positive effect only on denitrification rates at the middle incubation depth at all stations. Nitrous oxide was in some incubations a significant product of denitrification varying from below detection to $44 \%$ of the total $\mathrm{N}_{2}+\mathrm{N}_{2} \mathrm{O}$ gas production (St. F, $131.5 \mathrm{~m}$, +sulfide).

The effect of sulfide concentration on denitrification rates was different between the stations in 2010 (Fig. 3). At station D there was no effect of sulfide on denitrification at all and the rates recorded at the different sulfide concentrations were not different. At the other two stations denitrification rates increased more or less linearly with sulfide concentration. A linear regression, forced through origin because no sulfide resulted in no denitrification, allowed calculation of denitrification at St. F and Z in 2010 at any given sulfide concentration as: denitrification $=[$ sulfide $] \times$ slope, where slope was $9.65\left(R^{2}=0.95\right)$ and 22.69 $\left(R^{2}=1.00\right)$ for stations $\mathrm{F}$ and $\mathrm{Z}$, respectively, and where denitrification is in $\mathrm{nM} \mathrm{N} \mathrm{h}^{-1}$ and sulfide concentration is in $\mu \mathrm{M}$. This relation and the in situ sulfide concentrations were used to calculate the in situ denitrification rates at these two stations. The relative importance of $\mathrm{N}_{2} \mathrm{O}$ production also increased with increased sulfide at these two stations from undetectable at the lowest sulfide concentrations to $75 \%$ and $83 \%$ of the total N-gas production at stations $\mathrm{Z}$ and $\mathrm{F}$, respectively.

Also the effect of $\mathrm{NO}_{x}^{-}$concentration was very different between the stations in 2010 (Fig. 4). At St. D there was a perfectly linear correlation between $\mathrm{NO}_{x}^{-}$concentration and rate of denitrification up to a concentration of $5 \mu \mathrm{M} \mathrm{NO}_{3}^{-}$, whereas the $\mathrm{NO}_{3}^{-}$concentration had no effect at the other two stations. At St. D a linear regression, forced through origin because no $\mathrm{NO}_{x}^{-}$is expected to result in no denitrification, allowed the calculation of in situ denitrification as: denitrification $=\left[\mathrm{NO}_{x}^{-}\right] \times 17.86\left(R^{2}=1.00\right)$, where units are $\mathrm{nM} \mathrm{Nh}^{-1}$ for denitrification and $\mu \mathrm{M}$ for $\left[\mathrm{NO}_{x}^{-}\right]$ (Fig. 4). In 2008 denitrification rates were measured at $10 \mu \mathrm{M} \mathrm{NO}_{x}^{-}$, and thus in the range where denitrification was saturated with $\mathrm{NO}_{x}^{-}$according to the 2010 experiments. We assumed that the relative change in denitrification rate as a function of $\mathrm{NO}_{x}^{-}$concentration in 2008 was the same as at St. D in 2010. Here denitrification was proportional to the $\mathrm{NO}_{x}^{-}$concentration in the $0-5 \mu \mathrm{M}$ range, where the rate increased by a value equal to $20.2 \%$ of the rate measured at saturating $\mathrm{NO}_{x}^{-}$concentrations for an increase of $1 \mu \mathrm{M}$

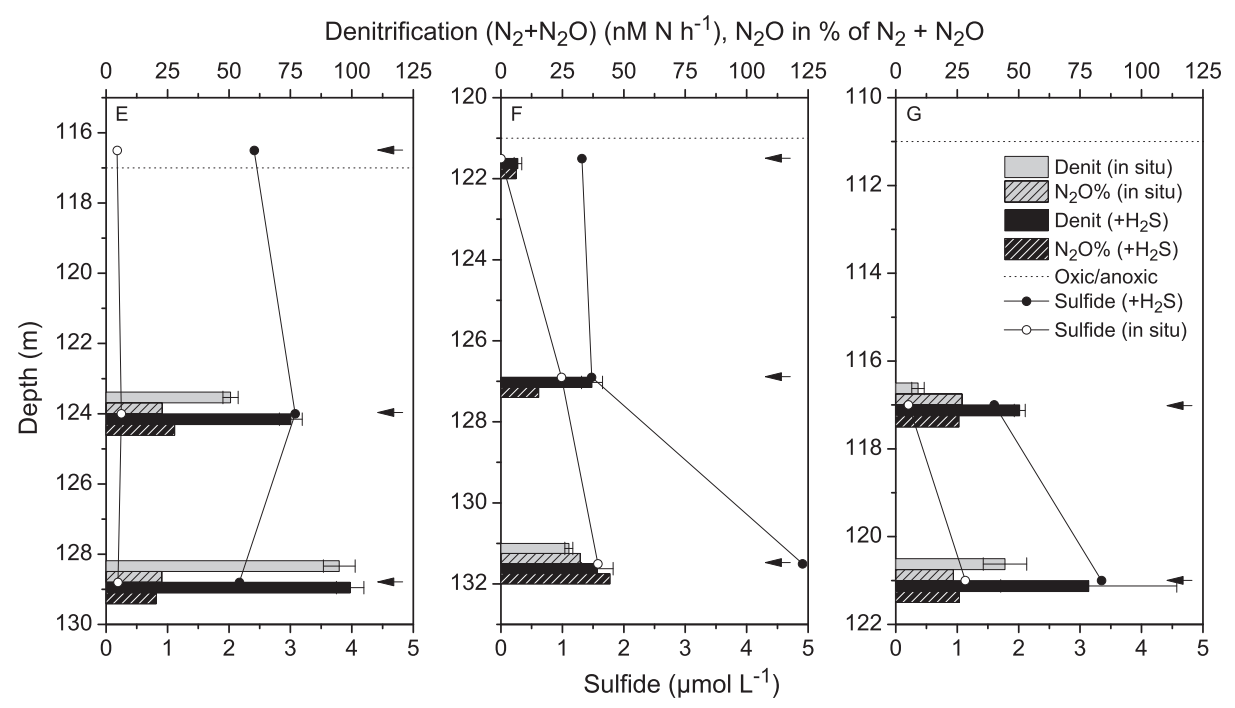

Fig. 2. Total denitrification rates $\left(\mathrm{N}_{2}+\mathrm{N}_{2} \mathrm{O}\right.$ production) and the $\mathrm{N}_{2} \mathrm{O}$ production in $\%$ of the total N-gas production at in situ sulfide concentration (in situ) and with sulfide amendment $\left(+\mathrm{H}_{2} \mathrm{~S}\right)$. Dotted line indicate the oxic-anoxic interface. Points and lines indicate sulfide concentrations. Arrows indicate depths sampled for incubations. Data from 2008 for stations E-G as indicated. Error bars show the standard error of the mean. Note differences in depth scales. 

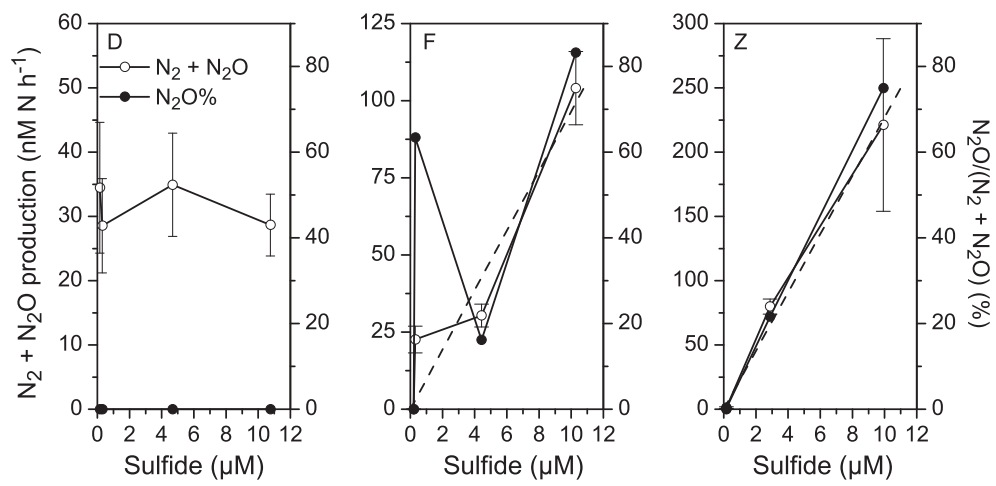

Fig. 3. Total denitrification $\left(\mathrm{N}_{2}+\mathrm{N}_{2} \mathrm{O}\right.$ production) and the $\mathrm{N}_{2} \mathrm{O}$ production in $\%$ of total denitrification as a function of sulfide concentrations. Data from 2010, stations D, F, and Z as indicated. For stations F and Z regression lines are shown (dashed lines, see text for equations) for total denitrification as a function of sulfide concentration assuming no denitrification at no sulfide. Error bars show the standard error of the mean. Note differences in $y$-axis scales.
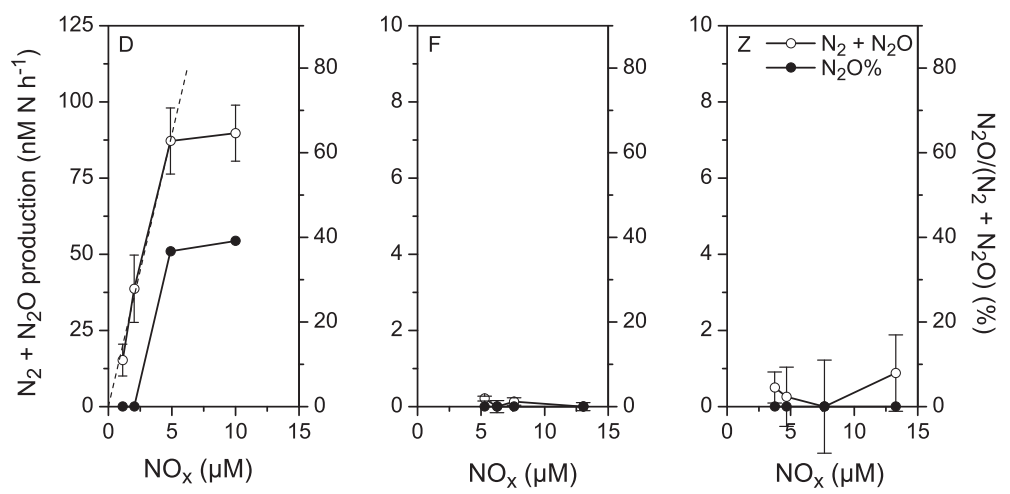

Fig. 4. Total denitrification $\left(\mathrm{N}_{2}+\mathrm{N}_{2} \mathrm{O}\right.$ production) and the $\mathrm{N}_{2} \mathrm{O}$ production in $\%$ of total denitrification as a function of $\mathrm{NO}_{x}^{-}$ concentrations. Data from 2010, stations D, F, and Z as indicated. For station D a regression line is shown for denitrification as a function of $\mathrm{NO}_{x}^{-}$assuming no denitrification at no $\mathrm{NO}_{x}^{-}$(dashed line, see text for the equation). At stations $\mathrm{F}$ and $\mathrm{Z}$ rates were not significantly different from zero $(p=0.05)$ except for the lowest $\mathrm{NO}_{x}^{-}$concentration at station F. Error bars show the standard error of the mean. Note differences in $y$-axis scales.

$\mathrm{NO}_{x}^{-}$. In situ denitrification in 2008 was thus calculated as: denitrification $_{\text {in situ }}=$ denitrification $_{\text {saturated }} \times\left[\mathrm{NO}_{x}^{-}\right] \times 0.2019$, where denitrification saturated $_{\text {is }}$ the rate of denitrification measured at $10 \mu \mathrm{M} \mathrm{NO}_{x}^{-}$, units are $\mathrm{nM} \mathrm{N} \mathrm{h}^{-1}$ for denitrification and $\mu \mathrm{M}$ for $\mathrm{NO}_{x}^{-}$concentration. The in situ $\mathrm{NO}_{x}^{-}$ concentrations in 2008 were $0.3-1.3 \mu \mathrm{M}$ and thus in the range where proportionality between $\mathrm{NO}_{x}^{-}$concentration and denitrification rate may be expected. Also the relative $\mathrm{N}_{2} \mathrm{O}$ production increased with $\mathrm{NO}_{x}^{-}$concentration reaching $39 \%$ of the total $\mathrm{N}$-gas production at the highest $\mathrm{NO}_{x}^{-}$ concentration. At the other two stations in 2010 denitrification was below detection without sulfide amendment except for one very low but significant rate recorded at $5 \mu \mathrm{M} \mathrm{NO}_{x}^{-}$ at station F. Nitrous oxide production was not detected at these two stations (Fig. 4).

Concentrations of $\mathrm{NO}_{3}^{-}$generally decreased during the incubations but because of the often relatively high concentrations and low consumption rates it was not possible to estimate the actual $\mathrm{NO}_{3}^{-}$reduction rates. Concentrations of $\mathrm{NO}_{2}^{-}$did not vary systematically during the incubations. In some incubations $\mathrm{NO}_{2}^{-}$was consumed, in some it was produced, and in some there was a transient accumulation (not shown).

\subsection{Water column profiles}

The water column was stratified in both years with a shallow thermocline at $15 \mathrm{~m}$ (2010) to $25 \mathrm{~m}$ (2008) depth (Fig. 5). A second density stratification, mainly caused by a salinity increase, was located deeper in the water column but always above the oxic-anoxic interface. The oxicanoxic interface was located further down at a depth where the density increased gently with depth and was never associated with abrupt changes in density. Water chemistry profiles generally showed strong changes around the oxicanoxic interface and example profiles from both 2008 and 2010 are shown in Fig. 6. Nitrate was generally present above the interface but decreased to zero just below whereas sulfide showed the opposite trend. It reached high concentrations in the deep and declined rapidly towards the interface but due to the relatively coarse depth resolution it was not possible to see whether or not sulfide crossed the 


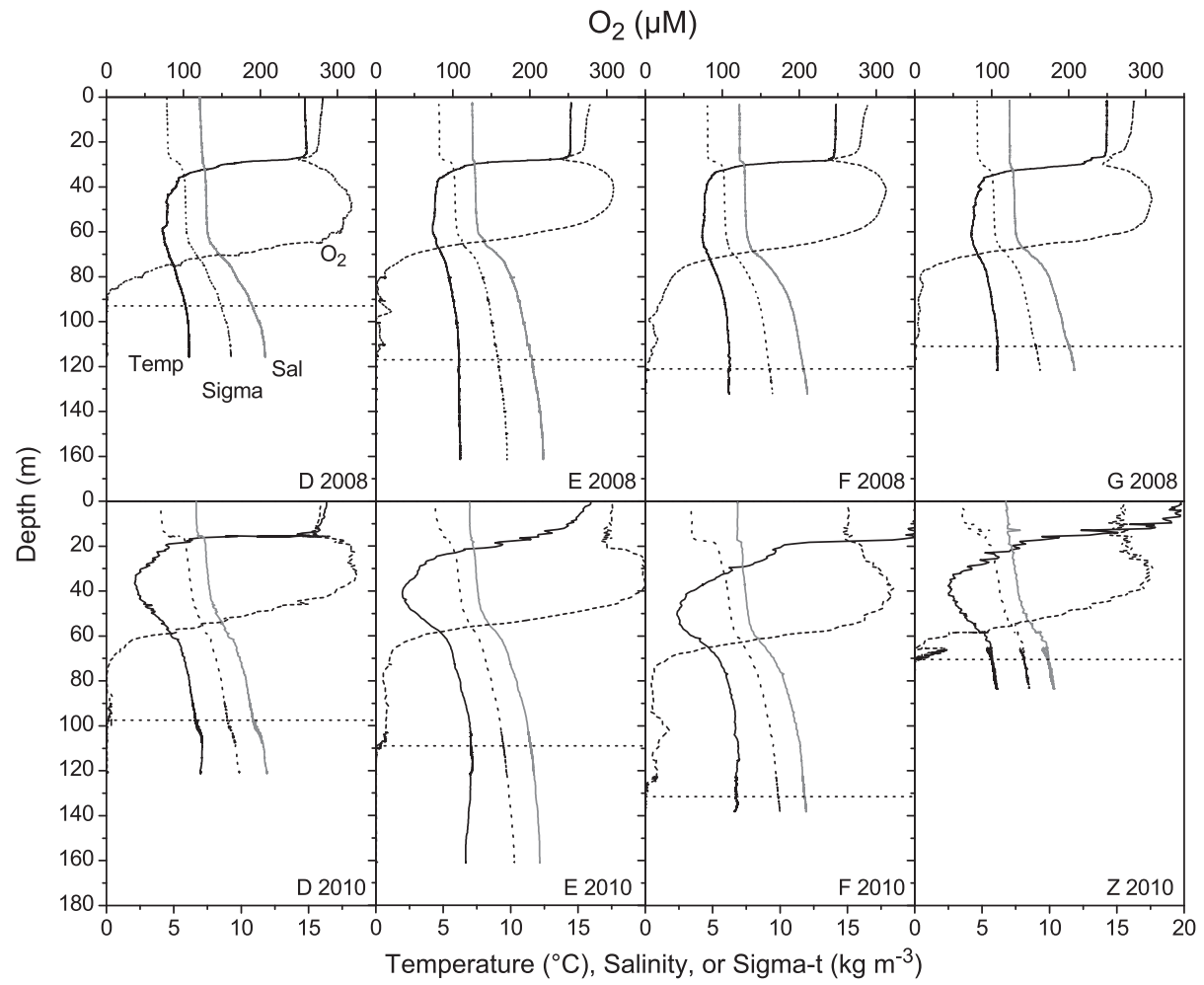

Fig. 5. Depth profiles of $\mathrm{O}_{2}$, temperature, salinity, and density (shown as Sigma-t) for all four stations in both years as indicated. Dashed horizontal line indicates the oxic-anoxic interface.

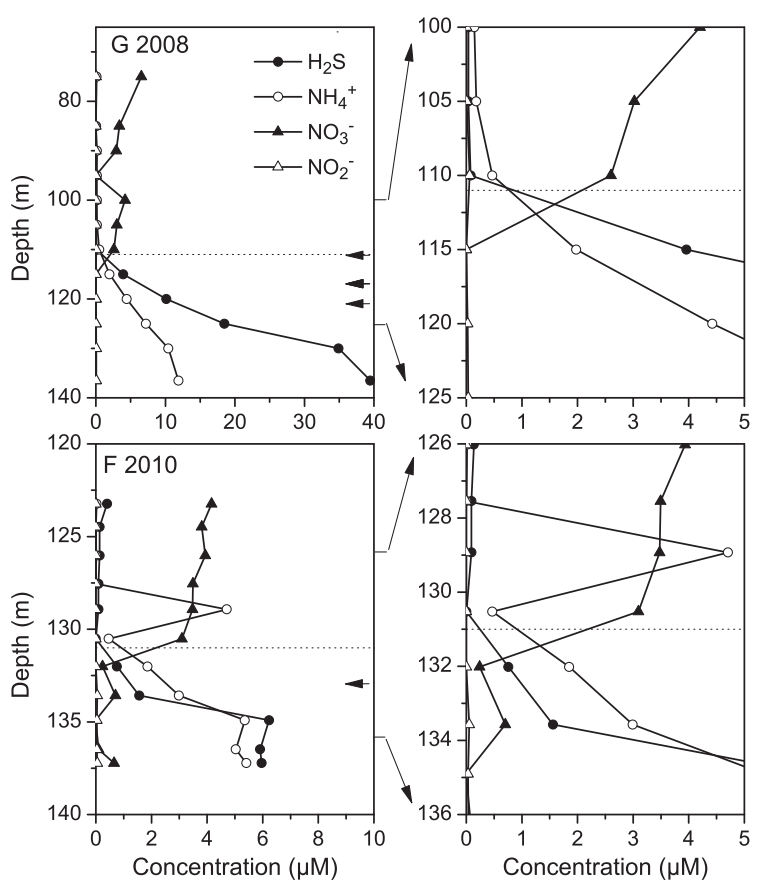

Fig. 6. Water chemistry depth profiles at station $\mathrm{G}$ in 2008 and $\mathrm{F}$ in 2010. Left hand panels show the full profile, right hand panels show details around the oxic-anoxic interface which is indicated by the dotted line. Arrows indicate depths sampled for incubations.
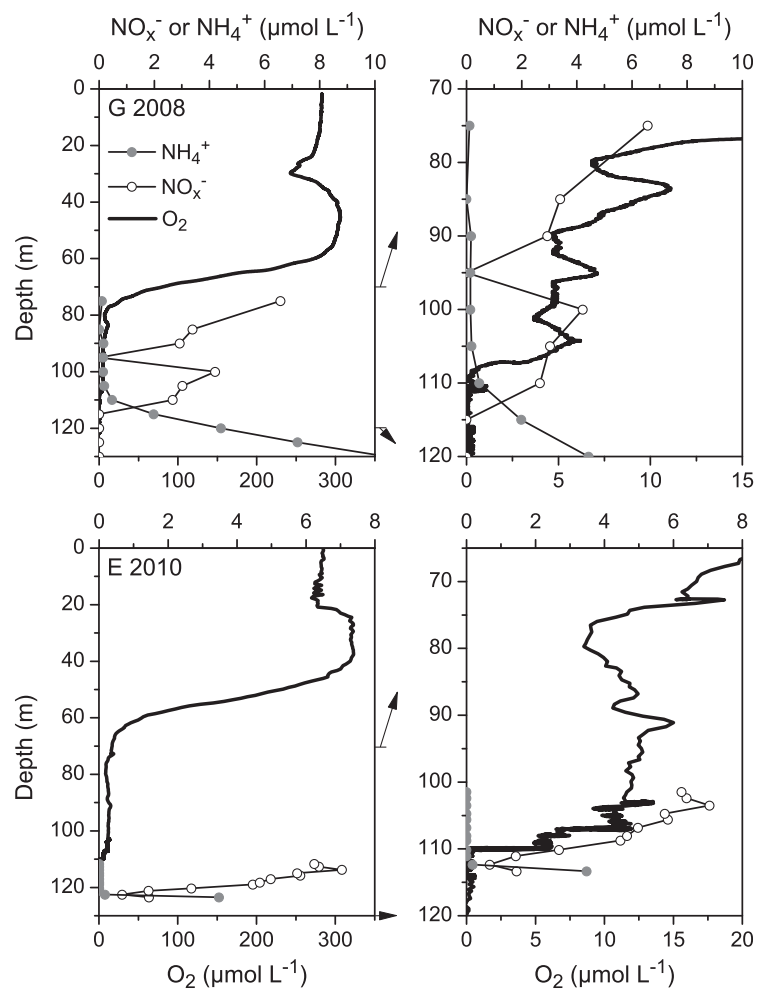

Fig. 7. Water chemistry depth profiles at stations $G$ in 2008 (upper) and E in 2010 (lower). Left hand panels show the full profile, right hand panels show details for the depth intervals with low $\mathrm{O}_{2}$ concentrations. 
oxic-anoxic interface. Ammonium followed almost the same pattern with high concentrations in the deep and was often present in the first couple of meters above the oxic-anoxic interface. This was only visible in the 2010 samplings with sampling at $1 \mathrm{~m}$ intervals while with $5 \mathrm{~m}$ intervals in $2008 \mathrm{NH}_{4}^{+}$was always below detection in the first sample above the interface. Water column profiles also showed interesting features on the larger scale and both in 2008 and 2010 there were extensive water layers where oxygen was higher than zero and lower than approximately $10 \mu \mathrm{M}$ (Fig. 7, Table 2). The thickness of these layers was generally in the range $22-55 \mathrm{~m}$ with station D in 2008 and $\mathrm{Z}$ in 2010 as exceptions with a thickness of only $4 \mathrm{~m}$.

\section{DISCUSSION}

We visited several stations in the EGB in 2008 and 2010 and we found denitrification to be responsible for all removal of fixed nitrogen and there was no indication of anammox in any of the incubations. Overall this agrees very well with earlier findings of denitrification in the EGB (Brettar and Rheinheimer, 1991, 1992; Hannig et al., 2007; Hietanen et al., 2012). Significant contribution of anammox to total $\mathrm{N}_{2}$ production has only been found after a major inflow event. During such an event the anoxic and often sulfidic bottom water of the EGB is replaced with oxic water and during the following stagnation period $\mathrm{O}_{2}$ gets depleted and sulfide subsequently accumulates in the bottom water (Hannig et al., 2007). During the period from $\mathrm{O}_{2}$ depletion until sulfide accumulation, only anammox and not denitrification could be detected (Hannig et al., 2007). The relatively high concentrations of sulfide below the oxic-anoxic interface during our cruises indicate that a major inflow had not recently taken place and the absence of anammox was thus expected. These results support the conclusion of Jensen et al. (2009) based on studies in the sulfidic Mariager Fjord (Denmark) that anammox will only be important in anoxic sulfide free waters, whereas denitrification will dominate when sulfide is available.

\subsection{Denitrification and oxygen}

In agreement with Brettar and Rheinheimer (1991), Hannig et al. (2007), and Hietanen et al. (2012) we did not find denitrification if $\mathrm{O}_{2}$ was detectable in situ. Denitrification generally occurred closely below the oxic-anoxic interface in 2008 and the single incubation of water sampled above this interface did not show any denitrification (St. E, $116.5 \mathrm{~m}$, Fig. 2). Denitrification was also found right below (3-3.5 m) the oxic-anoxic interface in 2010. In agreement with this, most earlier reports have found denitrification to occur closely below this interface (Brettar and Rheinheimer, 1991; Hannig et al., 2007; Jensen et al., 2009). One exception from this is a study of the EGB and Landsort Deep where denitrification was only found much deeper into the anoxic zone and mostly at high sulfide concentrations (Hietanen et al., 2012), but this may be explained as a methodological issue. Water samplers made from PVC, which were used in this and all the cited studies, contaminate anoxic samples with $\mathrm{O}_{2}$. Oxygen is soluble in PVC and this is released to the water sample, similar to the way $\mathrm{O}_{2}$ is released from rubber septa to the contents of a vial (De Brabandere et al., 2012), and even if water sampled at anoxic depth is transferred from the water sampler to glass bottles with several times overflow it will not be anoxic after this transfer. Therefore, our protocol involved gassing of the sample with $\mathrm{He}$ and, in 2010, incubations were additionally done with $\mathrm{O}_{2}$ depleted septa and a $\mathrm{He}$ headspace to remove $\mathrm{O}_{2}$ contamination (De Brabandere et al., 2012). In the previous studies of the Baltic Sea, removal of $\mathrm{O}_{2}$ contamination was only done by Hannig et al. (2007). Oxygen contamination in the incubation vials may lead to underestimation of anammox and denitrification depending on the incubation procedure. Brettar and Rheinheimer (1991) incubated for 12 days and $\mathrm{O}_{2}$ consumption in the incubated water was most likely sufficient to make the sample anoxic early in the incubation and denitrification could thus take place. However, in short term incubations ( $32 \mathrm{~h}$; Hietanen et al., 2012) this may not be the case depending on the $\mathrm{O}_{2}$ consumption rate. Oxygen consumption may be controlled by the availability of reducing equivalents and when sulfide concentrations were high, $\mathrm{O}_{2}$ consumption may have created anoxia relatively fast and denitrification may have been recorded. This mechanism may explain why the quantitatively significant rates, in that study, were found only relatively far below the oxic-anoxic interface where sulfide concentrations were high $(11-62 \mu \mathrm{M})$. This may also explain why denitrification was not seen at all by Hietanen et al. (2012) when sulfide was below $5 \mu \mathrm{M}$ even when $\mathrm{O}_{2}$ was not detectable in situ, and why we and Brettar and Rheinheimer (1991) found denitrification closely below the oxic-anoxic interface. We thus propose that denitrification in such anoxic basins with sulfidic bottom water generally occurs most intensively closely below the oxic-anoxic interface, where $\mathrm{NO}_{x}^{-}$and sulfide are present and oxygen is absent.

\subsection{Regulation of denitrification}

The electron donor for denitrification in anoxic water columns in anoxic basins has often been shown to be sulfide, coming from below, meeting with $\mathrm{NO}_{3}^{-}$, coming from above, at the sulfide- $\mathrm{NO}_{3}^{-}$interface (Brettar and Rheinheimer, 1991, 1992; Hannig et al., 2007; Jensen et al., 2009; Hietanen et al., 2012). In most situations we also found sulfide to be an important electron donor for denitrification in the EGB. In four of the incubations in 2008 denitrification was stimulated by sulfide amendment (Fig. 2). The response was immediate, as indicated by the linear increase of ${ }^{15} \mathrm{~N}$-labeled $\mathrm{N}_{2}$ with time (not shown), suggesting that denitrification with sulfide as electron donor was active in situ. In 2010 denitrification was proportional to sulfide concentrations at St. F and Z, which indicates that sulfide was the electron donor. The linearity between denitrification and sulfide concentration continued to the highest concentrations applied (ca. $10 \mu \mathrm{M}$, Fig. 3) and there was no sign of saturation. Jensen et al. (2009) found similarly that $\mathrm{NO}_{2}^{-}$ reduction rates increased linearly with sulfide concentrations up to at least $40 \mu \mathrm{M}$ in the anoxic water column of the Mariager Fjord. At St. D, however, denitrification 
was independent of the sulfide concentration (Fig. 3). The lowest sulfide concentration here was $0.16 \mu \mathrm{M}$ and, given the response of denitrification to sulfide amendments at the other two stations, it is clear that sulfide did not play a role in denitrification at St. D. Instead it was most likely organic matter that was the electron donor for denitrification here and we believe that this is the first clear demonstration of heterotrophic denitrification in anoxic water columns of the Baltic Sea. However, it should be noted that even though sulfide amendment stimulated denitrification in 2008, sulfide may not be the only electron donor here and organic matter may play a role as well. It is only in the incubations from 2010, where denitrification required sulfide, that denitrification can be concluded to be driven by sulfide alone. The addition of glucose stimulated denitrification (Rönner and Sörensson, 1985), but with incubation times of 1-4 weeks this is not an indication of in situ denitrification being powered by organic matter.

The ratios of $\left(\mathrm{N}_{2}+\mathrm{N}_{2} \mathrm{O}\right)-\mathrm{N}$ production to sulfide consumption may be used as an indicator of the stoichiometry of the sulfide oxidation. If the reaction between sulfide and $\mathrm{NO}_{3}^{-}$results in the formation of $\mathrm{N}_{2}$ and $\mathrm{SO}_{4}^{2-}$ this ratio will be 1.6 but if instead the oxidation product is $\mathrm{S}^{0}$ the ratio will be 0.4 . In our experiments both sulfide and organic matter might have been electron donors and $\mathrm{N}_{2}+\mathrm{N}_{2} \mathrm{O}$ production may not reflect only sulfide oxidation. Thus the ratio of $\left(\mathrm{N}_{2}+\mathrm{N}_{2} \mathrm{O}\right)-\mathrm{N}$ production to sulfide consumption may become overestimated. However, in the experiments with the highest sulfide concentrations (stations F and $\mathrm{Z}, 10 \mu \mathrm{M}$ sulfide added, Fig. 3) we may assume that sulfide is the by far most important electron donor and the ratios here were 0.18 and 0.28 for stations $\mathrm{F}$ and $\mathrm{Z}$, respectively. This is somewhat lower than the theoretical values, probably due to small analytical inaccuracies, but overall indicates that $\mathrm{S}^{0}$ was the major oxidation product just as it was in Mariager Fjord (Jensen et al., 2009).

Beside acting as electron donor for denitrification, sulfide is also known to inhibit the reduction of $\mathrm{N}_{2} \mathrm{O}$ to $\mathrm{N}_{2}$ in the denitrification pathway (Sørensen et al., 1980) and the inhibition of the enzymes leading to the formation of $\mathrm{N}_{2} \mathrm{O}$ is less than that of $\mathrm{N}_{2} \mathrm{O}$ reduction itself (Schönharting et al., 1998). There was a clear inhibition in the 2010 incubations where sulfide was utilized as electron donor (Fig. 3) and the $\mathrm{N}_{2} \mathrm{O}$ fraction of the total denitrification $\left(\mathrm{N}_{2}+\mathrm{N}_{2} \mathrm{O}\right)$ increased almost linearly with sulfide concentration and reached ca. $70 \%$ at $10 \mu \mathrm{M}$ sulfide. It might be expected that denitrifiers using sulfide as a substrate may be less sensitive to the sulfide inhibition of $\mathrm{N}_{2} \mathrm{O}$ reduction, however, the strong inhibition seen in the 2010 experiments indicates that $\mathrm{N}_{2} \mathrm{O}$ reduction in such organisms is also highly sensitive to sulfide. Production of $\mathrm{N}_{2} \mathrm{O}$ by denitrification was also significant in 2008 even at in situ sulfide concentrations (Fig. 2). In situ denitrification with sulfide will occur in the zone where $\mathrm{NO}_{x}^{-}$and sulfide coexist. Given the relation between sulfide and $\mathrm{N}_{2} \mathrm{O}$ production found here it is likely that the highest $\mathrm{N}_{2} \mathrm{O}$ production will occur deepest in this zone where sulfide concentrations are highest. If this $\mathrm{N}_{2} \mathrm{O}$ is transported downwards it is most likely consumed by denitrification. However, if it is transported upwards, and not reduced during its passage through the denitrification zone, and reaches the oxic waters above, it may contribute to the general $\mathrm{N}_{2} \mathrm{O}$ supersaturation of the central Baltic Sea (Rönner, 1983; Brettar and Rheinheimer, 1991). However, it appears that denitrification is able to consume most of the produced $\mathrm{N}_{2} \mathrm{O}$ during stable anoxic periods and that large production of mainly occurs during transition from oxic to anoxic conditions (Naqvi et al., 2010). Surprisingly Hietanen et al. (2012) only found complete denitrification to $\mathrm{N}_{2}$ and no accumulation of $\mathrm{N}_{2} \mathrm{O}$. Similarly, we did not find any $\mathrm{N}_{2} \mathrm{O}$ production in the presence of sulfide when sulfide was not the electron donor (Fig. 3, St. D) even though the inhibition of $\mathrm{N}_{2} \mathrm{O}$ reduction to $\mathrm{N}_{2}$ by sulfide has been shown to occur in heterotrophic denitrification (Sørensen et al., 1980). An alternative explanation for the accumulation of $\mathrm{N}_{2} \mathrm{O}$ in sulfide driven denitrification could be the enhancement of denitrification by organisms lacking the $\mathrm{N}_{2} \mathrm{O}$ reductase as is the case for the SUP05 type of organism known from anoxic water columns (Walsh et al., 2009).

The concentration of $\mathrm{NO}_{x}^{-}$played a critical role in the regulation of denitrification rates (Fig. 4). Unfortunately the $\mathrm{NO}_{x}^{-}$concentration experiments at $\mathrm{St} . \mathrm{F}$ and $\mathrm{Z}$ were performed with only 0.14 and $0.17 \mu \mathrm{M}$ sulfide, respectively, which was not enough to drive denitrification. At St. D, however, denitrification was proportional to the $\mathrm{NO}_{x}^{-}$concentration from zero to $4.9 \mu \mathrm{M}$ above which it became saturated at a rate of ca. $90 \mathrm{nM} \mathrm{N} \mathrm{h}^{-1}$ (Fig. 4 St. D). We would have expected a Michaelis-Menten kind of relationship as found for Mariager Fjord (Jensen et al., 2009), and we cannot explain why this was not the case. We found a maximal rate of denitrification of $250 \mathrm{nM} \mathrm{N} \mathrm{h}^{-1}$ at $10 \mu \mathrm{M}$ sulfide which falls within the range of rates found by Hietanen et al. (2012) who found a maximal rate of $390 \mathrm{nM} \mathrm{N} \mathrm{h}^{-1}$ at $21 \mu \mathrm{M}$ sulfide in the Gotland Deep. These maximal rates are potential rates measured with concentrations of $\mathrm{NO}_{x}^{-}$and sulfide significantly above the in situ values. Mariager Fjord had maximal denitrification rates 3.75.5 times higher than in the EGB, which may be caused by the highly eutrophic state of this Danish fjord. In our $\mathrm{NO}_{x}^{-}$ concentration experiment half-maximal denitrification was reached at ca. $2.5 \mu \mathrm{M} \mathrm{NO} \mathrm{NO}_{x}^{-}$, which agrees very well with the Michaelis-Menten half-saturation constant from Mariager Fjord of $2.9 \mu \mathrm{M}$ for $\mathrm{NO}_{3}^{-}$dependent denitrification (Jensen et al., 2009).

\subsection{In situ denitrification}

In order to compare the potential rates presented above to published rates and to estimate removal of bioavailable nitrogen per unit area we must scale the potential rates to the in situ concentrations of sulfide and $\mathrm{NO}_{x}^{-}$. In 2008 incubations were done with $10 \mu \mathrm{M}^{15} \mathrm{NO}_{3}^{-}$and in situ sulfide concentrations and the measured rates were corrected to in situ $\mathrm{NO}_{x}^{-}$concentrations using the relationship of denitrification to $\mathrm{NO}_{x}^{-}$concentration found at St. D in 2010 (see Section 3.1 for details) (Fig 4). The in situ rates were calculated using the average $\mathrm{NO}_{x}^{-}$concentrations for the zone from the oxic-anoxic interface down to where $\mathrm{NO}_{x}^{-}$was zero. Using the average is valid because the maximal $\mathrm{NO}_{x}^{-}$concentration found at any depth within this interval 
was $4.6 \mu \mathrm{M}$, which is within the range where denitrification was proportional to $\mathrm{NO}_{x}^{-}$concentration. The precision of this estimate is limited by the rather coarse depth resolution in 2008 where we sampled at $5 \mathrm{~m}$ intervals (Fig. 6). Incubations at St. D failed in 2008 (Table 1) so rate measurements from the nearby St. G were used together with water column chemistry from St. D to estimate in situ denitrification here. Correction of measured potential rates to in situ rates at St. D in 2010 was done exactly as described above for the 2008 stations utilizing the proportionality of denitrification to $\mathrm{NO}_{x}^{-}$concentration. However, at $\mathrm{St} . \mathrm{F}$ and $\mathrm{Z}$ in 2010 denitrification was proportional to the sulfide concentration and in situ denitrification was, therefore, calculated from the relation between denitrification and sulfide concentration at each of these stations (Fig. 3) using the average sulfide concentration in the anoxic $\mathrm{NO}_{x}^{-}$containing zone. For St. E only water column profiles were available and in situ denitrification rates were estimated applying the relationship between denitrification and sulfide concentration from the nearby St. F.

The estimated in situ rates of denitrification per unit volume of water varied by two orders of magnitude and were generally higher in 2010 than in 2008 (Table 2). There is no obvious explanation for this although primary production, and the following biogeochemical processes in the water column, may have been smaller in 2008 than in 2010 because the former cruise was one month later in the year than the latter. Also the fact that the average $\mathrm{NO}_{x}^{-}$concentrations in the anoxic zone were ca. 3 times higher in 2010 than in $2008(1.9$ versus $0.7 \mu \mathrm{M})$ may have contributed to this difference. Nevertheless, the range of in situ denitrification rates $\left(0.24-15.9 \mathrm{nM} \mathrm{N}_{2} \mathrm{~h}^{-1}\right)$ compare really well to the rates of Hietanen et al. (2012) from the Gotland Deep $\left(0.03-16.8 \mathrm{nM} \mathrm{N}_{2} \mathrm{~h}^{-1}\right)$. Those rates were measured in March and September applying the ${ }^{15} \mathrm{~N}$ technique as in the present study. Denitrification measured with the acetylene inhibition technique, measured in the EGB in July and August, gave results in the lower range of what we find (0.92-2.29 $\mathrm{nM} \mathrm{N}_{2} \mathrm{~h}^{-1}$ ) (Brettar and Rheinheimer, 1991). However, these rates may be somewhat underestimated because the acetylene blockage may be partly alleviated in the presence of sulfide (Tam and Knowles, 1979; Dalsgaard and Bak, 1992). Furthermore, acetylene may change the oxidation product of sulfide from $\mathrm{SO}_{4}^{2-}$ in the absence of acetylene to elemental sulfur in the presence of acetylene (Dalsgaard and Bak, 1992). Thus each sulfide molecule donates only two electrons when oxidized to sulfur instead of eight when oxidized to $\mathrm{SO}_{4}^{2-}$. In situations with sulfide limited denitrification, as St. F and Z in 2010 and the Brettar and Rheinheimer (1991) measurements, this reduction in electron availability may have reduced denitrification, provided that $\mathrm{S}^{0}$ was not already the oxidation product. In the inner part of the Oslo Fjord, Norway, maximum rates of $31 \mathrm{nM} \mathrm{N} \mathrm{h}^{-1}$ were found with a ${ }^{15} \mathrm{~N}$ amendment technique

Table 1

Overview of the sampling and incubations and station characteristics.

\begin{tabular}{|c|c|c|c|c|c|c|c|}
\hline \multirow[t]{2}{*}{ Stations } & \multicolumn{2}{|c|}{ Incubations } & \multicolumn{2}{|c|}{ Water col. profiles } & \multirow[t]{2}{*}{ Dist. from Gotland $(\mathrm{km})$} & \multirow[t]{2}{*}{ Water depth (m) } & \multirow[t]{2}{*}{ Oxic-anoxic interface depth $(\mathrm{m})^{\mathrm{a}}$} \\
\hline & 2008 & 2010 & 2008 & 2010 & & & \\
\hline D & & $X$ & $X$ & $\mathrm{X}$ & 25 & 130 & 95 \\
\hline $\mathrm{E}$ & $\mathrm{X}$ & & $\mathrm{X}$ & $\mathrm{X}$ & 47 & 170 & 113 \\
\hline $\mathrm{F}$ & $\mathrm{X}$ & $X$ & $X$ & $X$ & 55 & 210 & 126 \\
\hline G & $X$ & & $X$ & & 30 & 150 & 111 \\
\hline $\mathrm{Z}$ & & $X$ & & $X$ & 17 & 90 & 70 \\
\hline
\end{tabular}

a For stations samples in both 2008 and 2010, the depth of the oxic-anoxic interface is given as the average of the depth for each year.

Table 2

Thicknesses of the layers with $\mathrm{O}_{2}$ concentrations below detection and detectable $\mathrm{NO}_{x}^{-}$, and the layers with $\mathrm{O}_{2}$ between 0 and $10 \mu \mathrm{M}$, the denitrification in the anoxic $\mathrm{NO}_{x}^{-}$containing layer, and the eddy diffusion coefficient $\left(K_{z}\right)$ required for a $\mathrm{NO}_{x}^{-}$transport to the denitrification zone sustaining the measured denitrification.

\begin{tabular}{|c|c|c|c|c|c|c|c|c|}
\hline \multirow[t]{3}{*}{ Station } & \multirow[t]{3}{*}{ Year } & \multicolumn{2}{|l|}{ Thickness of layers (m) } & \multicolumn{4}{|c|}{ In situ denitrification } & \multirow{3}{*}{$\begin{array}{l}\text { Required } K_{z} \\
10^{-5} \mathrm{~m}^{2} \mathrm{~s}^{-1}\end{array}$} \\
\hline & & \multirow[t]{2}{*}{ Anoxic $\mathrm{NO}_{x}^{-}$containing } & \multirow[t]{2}{*}{$\overline{\mathrm{O}_{2}}=0-10 \mu \mathrm{M}$} & \multicolumn{2}{|c|}{$\mathrm{nM} \mathrm{N}_{2} \mathrm{~h}^{-1}$} & \multicolumn{2}{|c|}{$\mathrm{mmol} \mathrm{N} \mathrm{m}^{-2} \mathrm{~d}^{-1}$} & \\
\hline & & & & Rate & $\pm \mathrm{SE}$ & Rate & $\pm \mathrm{SE}$ & \\
\hline D & 2008 & 15.0 & 4.5 & 2.41 & 0.07 & 1.74 & 0.05 & 4.8 \\
\hline $\mathrm{E}$ & 2008 & 6.0 & 34.6 & 1.95 & 0.05 & 0.56 & 0.01 & 1.9 \\
\hline $\mathrm{F}$ & 2008 & 5.5 & 22.0 & 0.24 & 0.00 & 0.06 & 0.00 & 0.1 \\
\hline G & 2008 & 4.0 & 32.6 & 3.60 & 0.10 & 0.69 & 0.02 & 1.5 \\
\hline $\mathrm{D}$ & 2010 & 3.2 & 30.4 & 11.32 & 1.78 & 2.06 & 0.32 & 1.2 \\
\hline $\mathrm{E}$ & 2010 & 3.6 & 35.4 & 15.91 & 2.50 & 1.80 & 0.32 & 1.5 \\
\hline $\mathrm{F}$ & 2010 & 4.3 & 55.1 & 10.30 & 1.85 & 2.11 & 0.38 & 1.2 \\
\hline $\mathrm{Z}$ & 2010 & 4.9 & 4.0 & 5.32 & 1.29 & 0.36 & 0.09 & 2.2 \\
\hline Average & 2008 & - & - & 2.05 & 0.70 & 0.76 & 0.35 & \\
\hline Average & 2010 & - & - & 10.72 & 2.17 & 1.58 & 0.41 & \\
\hline
\end{tabular}


(Kristiansen and Schaanning, 2002), but these rates may be explained by the very long incubation time of 20 days which is known to give unrealistically high rates (Thamdrup et al., 2006). Estimates of in situ sulfide fueled denitrification with the ${ }^{15} \mathrm{~N}$ amendment technique in Mariager Fjord exceeded our rates by an order of magnitude $\left(246 \mathrm{nM} \mathrm{N}_{2} \mathrm{~h}^{-1}\right)$ (Jensen et al., 2009). Incubation times here were $30-50 \mathrm{~h}$ and the high rates are probably realistic and due to the highly eutrophic status of this fjord.

The above rates of denitrification per unit volume of water can be converted into rates per unit area by multiplying with the thickness of the denitrification zone. We estimated this from the water chemistry (Fig. 6) and found thicknesses of the anoxic $\mathrm{NO}_{x}^{-}$containing layers between 3.1 and $15 \mathrm{~m}$. We argue that this zone is equivalent to the denitrification zone as the process occurred in all our incubations from below the oxic-anoxic interface. See the discussion above as to why some earlier studies did not find denitrification right below the oxic-anoxic interface. The sampling interval of ca. $1 \mathrm{~m}$ in 2010 clearly gave a better estimate of the dimensions of this zone than did the ca. $5 \mathrm{~m}$ intervals in 2008, when we may have overestimated the thickness of the zone. However, if the thickness of the zone was overestimated the calculated average $\mathrm{NO}_{x}^{-}$concentration would be underestimated, and because of the proportionality of $\mathrm{NO}_{x}^{-}$concentrations and denitrification rates this would still be a correct calculation of the denitrification rate per unit area.

The estimates of in situ denitrification ranged from 0.06 to $2.11 \mathrm{mmol} \mathrm{N} \mathrm{m}^{-2} \mathrm{~d}^{-1}$ with averages of 0.76 and $1.58 \mathrm{mmol} \mathrm{N} \mathrm{m} \mathrm{N}^{-2} \mathrm{~d}^{-1}$ for 2008 and 2010, respectively (Table 2), comparing well to previous estimates. Brettar and Rheinheimer (1991) estimated denitrification in the EGB to be between 0.22 and $2.2 \mathrm{mmol} \mathrm{N} \mathrm{m}^{-2} \mathrm{~d}^{-1}$. Also in the EGB Hietanen et al. (2012) estimated denitrification to be $21 \mathrm{mmol} \mathrm{N} \mathrm{m}{ }^{-2} \mathrm{~d}^{-1}$ which is about one order of magnitude higher than our maximal rates. However, as discussed above the rate per unit volume was very similar to our rates and the discrepancy of rates per unit area is due to the fact that denitrification was estimated to occur in a $50 \mathrm{~m}$ thick layer, whereas our denitrifying layers were only a few meters thick. The finding of $\mathrm{NO}_{x}^{-}$down to at least $50 \mathrm{~m}$ below the oxic-anoxic interface was argued to be a transient phenomenon and $\mathrm{NO}_{x}^{-}$at these depths will not be replenished regularly (Hietanen et al., 2012).

\subsection{Denitrification and mixing events}

From the above discussion it is clear that denitrification will occur whenever sulfide and $\mathrm{NO}_{x}^{-}$coexist under anoxic conditions and in some cases also in the absence of sulfide. Sulfate reduction in the anoxic part of the basin produces this sulfide whereas $\mathrm{NO}_{x}^{-}$originates from nitrification in the oxic part of the water column or, alternatively, may be supplied by runoff from land. Coexistence of $\mathrm{NO}_{x}^{-}$and sulfide, therefore, requires mixing of waters across the oxic-anoxic interface. Such mixing may occur via turbulent motions induced by internal waves and mesoscale eddies (Lass et al., 2003). We argue that this mixing transports $\mathrm{NO}_{x}^{-}$from above and sulfide from below into the denitrification zone. The rate of transport depends on the sulfide and $\mathrm{NO}_{x}^{-}$concentration gradients and the eddy diffusivity ( $K_{z}$, Eq. (3)). Assuming that the only fate of $\mathrm{NO}_{x}^{-}$transported into this zone was denitrification the $K_{z}$ required to sustain the measured denitrification rate was calculated from Eq. (3). Except for one very low estimate of $0.1 \times 10^{-5} \mathrm{~m}^{2} \mathrm{~s}^{-1}$ the values ranged between $1.2 \times 10^{-5}$ and $4.8 \times 10^{-5} \mathrm{~m}^{2} \mathrm{~s}^{-1}$ with a median of $1.5 \times 10^{-5} \mathrm{~m}^{2} \mathrm{~s}^{-1}$ (Table 2). This agrees very well with the values from $0.2 \times 10^{-5}$ to $4.2 \times 10^{-5} \mathrm{~m}^{2} \mathrm{~s}^{-1}$, with medians of $0.8 \times 10^{-5}$ and $2.4 \times 10^{-5} \mathrm{~m}^{2} \mathrm{~s}^{-1}$ for summer and fall, respectively, found at $150 \mathrm{~m}$ depth in the Gotland Deep over a 30 year period (Axell, 1998) and the winter value of $0.8 \times 10^{-5} \mathrm{~m}^{2} \mathrm{~s}^{-1}$ below the halocline in the Gotland Basin (Lass et al., 2003). Our estimates of denitrification using short term bottle incubations thus appear to match the rates that may be expected from the water chemistry and hydrography. The same type of comparison is not possible for sulfide because at some stations part of the sulfide passed through the denitrification zone and was recorded above the oxic-anoxic interface. Furthermore, the vertical resolution, especially in 2008, was too coarse to decide whether or not all sulfide was consumed inside the denitrification zone. The sulfide flux is, therefore, not necessarily a measure of the rate of sulfide oxidation by denitrification.

The small scale vertical mixing due to turbulent motions induced by internal waves requires less energy and will occur more frequently than large scale vertical mixing, which may occur during severe wind events. We generally found anoxic $\mathrm{NO}_{x}^{-}$containing zones with a thickness of 3-6 m with one exception (Table 2) and we suggest that this is the thickness of the denitrification zone that can be maintained by small scale mixing. The average in situ volumetric denitrification rates from 2010 (volumetric rates from 2008 may be underestimated, see above) was about $0.5 \mu \mathrm{M}$ $\mathrm{N} \mathrm{d}^{-1}$ and given that the maximum $\mathrm{NO}_{x}^{-}$concentration below the oxic-anoxic interface was $4.6 \mu \mathrm{M}$ the lifetime of $\mathrm{NO}_{x}^{-}$here would be in the order of 9 days and less at lower $\mathrm{NO}_{x}^{-}$concentrations. The fact that we find this overlap of sulfide and $\mathrm{NO}_{x}^{-}$so consistently indicates that mixing must occur relatively frequently. Only once we observed an overlap of $15 \mathrm{~m}$ (St. D 2008, Table 2), which could indicate that mixing events of this magnitude occur much less frequently.

More intense mixing may create thick layers with low $\mathrm{O}_{2}$ concentrations, which may exist for a period of time during which nitrification produces $\mathrm{NO}_{x}^{-}$until $\mathrm{O}_{2}$ is again depleted. Once anoxia is established denitrification may consume the produced $\mathrm{NO}_{x}^{-}$. We observed such relatively thick oxic layers with $\mathrm{O}_{2}$ concentrations below $10 \mu \mathrm{M}$ (Fig. 7) and in six out of eight stations these layers were between 22 and $55 \mathrm{~m}$ thick (Table 2). Within these layers $\mathrm{NO}_{x}^{-}$ concentrations were up to $7 \mu \mathrm{M}$ and may increase even further before $\mathrm{O}_{2}$ is depleted, after which denitrification may pick up. These zones would thus be 4-11 times thicker than the anoxic $\mathrm{NO}_{x}^{-}$containing zones discussed above. Assuming that, after $\mathrm{O}_{2}$ has been depleted, the rate of denitrification in these zones per unit volume is similar to what we have measured in the present study, denitrification rates of $21 \mathrm{mmol} \mathrm{N} \mathrm{m} \mathrm{N}^{-2} \mathrm{~d}^{-1}$ (Hietanen et al., 2012) or even higher are certainly realistic. This mechanism may also explain 
the extremely high rates of denitrification observed in the Landsort Deep (Rönner and Sörensson, 1985). The authors found maximal volumetric denitrification rates of ca. $10 \mathrm{nM} \mathrm{N} \mathrm{h}^{-1}$, which is very similar to what we found, but because of an anoxic $\mathrm{NO}_{x}^{-}$containing layer with a thickness of $350 \mathrm{~m}$ the overall denitrification rate was ca. $90 \mathrm{mmol}$ $\mathrm{N} \mathrm{m}^{-2} \mathrm{~d}^{-1}$. Such high rates will only occur temporarily and the approximately $3.1 \mu \mathrm{M} \mathrm{NO}_{3}^{-}$that was present below $200 \mathrm{~m}$ in the Landsort Deep would be depleted after 13 days provided that the estimated denitrification rate does not change and that $\mathrm{NO}_{3}^{-}$is not resupplied.

The existence of denitrification in a few meter thick layer right below the oxic-anoxic interface at all the stations studied, indicates that this may occur more or less continuously. However, there must be a seasonal variation, which we are not able to resolve with measurements from the late summer only. With this limitation in mind we wish to compare the magnitude of denitrification in the water column to that occurring in sediments. Sediment denitrification in the Bothnian Sea and Bothnian Bay varied from 0 to $0.94 \mathrm{mmol} \mathrm{N} \mathrm{m}^{-2} \mathrm{~d}^{-1}$ (Stockenberg and Johnstone, 1997), in the Gulf of Finland from 0.1 to $0.65 \mathrm{mmol} \mathrm{N} \mathrm{m}^{-2} \mathrm{~d}^{-1}$ (Tuominen et al., 1998) and 0.091 to $0.4 \mathrm{mmol} \mathrm{N} \mathrm{m} \mathrm{N}^{-2}$ (Hietanen and Kuparinen, 2008), in the Northern Baltic Proper from 0.014 to $0.3 \mathrm{mmol} \mathrm{N} \mathrm{m}^{-2} \mathrm{~d}^{-1}$ (Tuominen et al., 1998), and in the Southern Baltic Proper from 0.012 to $0.69 \mathrm{mmol} \mathrm{N} \mathrm{m}^{-2} \mathrm{~d}^{-1}$ (Deutsch et al., 2010). The average water column denitrification rates from the present study, maintained by small scale mixing, thus in most cases exceed the recorded sediment denitrification rates. We thus suggest that water column denitrification generally exceeds sediment denitrification per unit area. Although we are not able to assess the quantitative contribution of episodic large scale mixing events, as discussed above, it appears that during such events water column denitrification may be orders of magnitude higher than sediment denitrification.

\subsection{Upscaling of denitrification to a basin-wide scale}

Hypoxia is a more or less permanent feature of the Baltic Proper (BP) with large inter annual variations in the hypoxic area (Conley et al., 2009). Although our data are limited to one season and all originate from the EGB, we want to upscale these to the whole BP to assess the possible role of water column denitrification in this part of the Baltic Sea. The upscaling is done for both the average rates from 2008 and 2010 and the areas where water column denitrification may occur have been estimated in different ways: All waters deeper than the average oxygen depletion depth in this study $(105 \mathrm{~m})$ (Table 3, A); the entire hypoxic area estimated by state of the art models (Eilola et al., 2011) (Table 3, B); the minimum (1993, Table 3, C) and maximum (2006, Table 3, D) hypoxic areas estimated by Conley et al. (2009). This approach resulted in denitrification rates be-

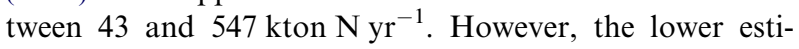
mate, which is based on the very low hypoxic area in 1993 right after a major inflow of oxygenated water, is probably an underestimate. The present day situation, where the hypoxic area of the BP is 3-6 times greater (Table 3), is probably better represented by the range of
Table 3

Denitrification in the water column of the Baltic Proper calculated from the rates measured in the present study in 2008 and 2010, and different estimates of the area where this occurs: (A) area where the water depth exceeds $105 \mathrm{~m}$ (B. Gustafsson, pers. comm.), (B) the average of the hypoxic area estimated by the four models applied by Eilola et al. (2011), (C) the minimum hypoxic area, and (D) the maximum hypoxic area estimated by Conley et al. (2009).

\begin{tabular}{llll}
\hline $\begin{array}{l}\text { Source of } \\
\text { area }\end{array}$ & $\begin{array}{l}\text { Area } \\
\left(\mathrm{km}^{2}\right)\end{array}$ & $\begin{array}{l}\text { Denitrification } 2008 \\
\left(\mathrm{kton} \mathrm{N} \mathrm{yr}^{-1}\right)\end{array}$ & $\begin{array}{l}\text { Denitrification 2010 } \\
\left(\mathrm{kton} \mathrm{N} \mathrm{yr}^{-1}\right)\end{array}$ \\
\hline A: Gustafsson & 33,763 & 132 & 273 \\
$\begin{array}{l}\text { B: Eilola } \\
\text { C: Conley }\end{array}$ & 55,000 & 214 & 444 \\
(min.) & 11,050 & 43 & 89 \\
$\begin{array}{l}\text { D: Conley } \\
\text { (max.) }\end{array}$ & 67,700 & 264 & 547 \\
\hline
\end{tabular}

132-547 kton $\mathrm{N} \mathrm{yr}^{-1}$. This fourfold variation reflects both variations in denitrification rates and hypoxic areas. In a recent nitrogen budget compiled by Deutsch et al. (2010) the sum of nitrogen loads to the BP from rivers and coastal point sources, atmospheric deposition, $\mathrm{N}_{2}$ fixation, and ex-

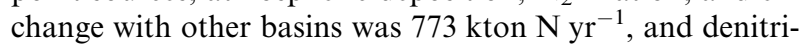
fication in the water column, as estimated in the present study, may actually remove a significant fraction of this. In this budget sediment denitrification in the BP was

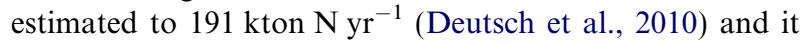
thus appears that water column denitrification may be even more important. This agrees well with a stable isotope nitrogen budget in which total denitrification in the BP amounted to $580-855 \mathrm{kton}^{\mathrm{N} \mathrm{yr}}{ }^{-1}$ (Voss et al., 2005). Assuming that sediment denitrification is $191 \mathrm{kton} \mathrm{N} \mathrm{yr}^{-1}$ this leaves $389-664 \mathrm{kton}^{\mathrm{N} \mathrm{yr}}{ }^{-1}$ to water column denitrification which is very similar to the range found in the present study (Table 3). However, it should be noted, that we base our estimates on relatively few sites and only one season, and to obtain a more robust estimate of basin-wide water column denitrification in the BP measurements should be performed on more locations and seasons.

\section{ACKNOWLEDGEMENTS}

We wish to thank the captain, crew and scientific party on board the University of Gothenburg RV Skagerak during the two cruises for excellent work and cooperation. Bo Gustafsson is acknowledged for providing bathymetric data for the Baltic Proper. This study was supported financially by the Swedish Research Council (VR) and the European Community's Seventh Framework Program (FP/2007-2013) under Grant agreement No. 226213, project "In situ monitoring of oxygen depletion in hypoxic ecosystems of coastal and open seas, and land-locked water bodies" (HYPOX). T.D. also received support by the European Community's Seventh Framework Program (FP/2007-2013) under Grant agreement No. 217246 made with Baltic Organizations Network for Funding Science EEIG (BONUS) project "Hypoxia Mitigation for Baltic Sea Ecosystem Restoration" (HYPER), the ERC Advanced Grant program through the "Oxygen" Grant, and the Arctic Research Centre at Aarhus University. Loreto De Brabandere was financially supported by the Agouron Institute and the Danish National Research Foundation. Two anonymous reviewers are acknowledged for their constructive comments and suggestions. 


\section{REFERENCES}

Axell L. B. (1998) On the variability of Baltic Sea deepwater mixing. J. Geophys. Res. [Oceans] 103, 21667-21682. http:// dx.doi.org/10.1029/98jc01714.

Braman R. S. and Hendrix S. A. (1989) Nanogram nitrite and nitrate determination in environmental and biological materials by vanadium (III) reduction with chemiluminescence detection. Anal. Chem. 61, 2715-2718.

Brettar I. and Rheinheimer G. (1991) Denitrification in the central Baltic - evidence for $\mathrm{H}_{2} \mathrm{~S}$-oxidation as motor of denitrification at the oxic-anoxic interface. Mar. Ecol. Prog. Ser. 77, 157-169.

Brettar I. and Rheinheimer G. (1992) Influence of carbon availability on denitrification in the central Baltic Sea. Limnol. Oceanogr. 37, 1146-1163.

Cline J. D. (1969) Spectrophotometric determination of hydrogen sulfide in natural waters. Limnol. Oceanogr. 14, 454-458.

Conley D. J., Bjorck S., Bonsdorff E., Carstensen J., Destouni G., Gustafsson B. G., Hietanen S., Kortekaas M., Kuosa H., Meier H. E. M., Muller-Karulis B., Nordberg K., Norkko A., Nurnberg G., Pitkanen H., Rabalais N. N., Rosenberg R., Savchuk O. P., Slomp C. P., Voss M., Wulff F. and Zillen L. (2009) Hypoxia-related processes in the Baltic Sea. Environ. Sci. Technol. 43, 3412-3420. http://dx.doi.org/10.1021/es802762a.

Conley D. J., Carstensen J., Aigars J., Axe P., Bonsdorff E., Eremina T., Haahti B. M., Humborg C., Jonsson P., Kotta J., Lannegren C., Larsson U., Maximov A., Medina M. R., Lysiak-Pastuszak E., Remeikaite-Nikiene N., Walve J., Wilhelms S. and Zillen L. (2011) Hypoxia is increasing in the coastal zone of the Baltic Sea. Environ. Sci. Technol. 45, 67776783. http://dx.doi.org/10.1021/es201212r.

Dalsgaard T. and Bak F. (1992) Effect of acetylene on nitrousoxide reduction and sulfide oxidation in batch and gradient cultures of Thiobacillus denitrificans. Appl. Environ. Microbiol. 58, 1601-1608.

Dalsgaard T., Canfield D. E., Petersen J., Thamdrup B. and Acuña-Gonzalez J. (2003) $\mathrm{N}_{2}$ production by the anammox reaction in the anoxic water column of Golfo Dulce, Costa Rica. Nature 422, 606-608.

De Brabandere L., Thamdrup B., Revsbech N. P. and Foadi R. (2012) A critical assessment of the occurrence and extend of oxygen contamination during anaerobic incubations utilizing commercially available vials. J. Microbiol. Methods 88, 147154. http://dx.doi.org/10.1016/j.mimet.2011.11.001.

Deutsch B., Forster S., Wilhelm M., Dippner J. W. and Voss M. (2010) Denitrification in sediments as a major nitrogen sink in the Baltic Sea: an extrapolation using sediment characteristics. Biogeosciences 7, 3259-3271. http://dx.doi.org/10.5194/bg-73259-2010.

Eilola K., Gustafsson B. G., Kuznetsov I., Meier H. E. M., Neumann T. and Savchuk O. P. (2011) Evaluation of biogeochemical cycles in an ensemble of three state-of-the-art numerical models of the Baltic Sea. J. Mar. Syst. 88, 267-284. http:// dx.doi.org/10.1016/j.jmarsys.2011.05.004.

Grasshoff K., Ehrhardt M. and Kremling K. (1983) Methods of Seawater Analysis, 2nd ed. Verlag Chemie GmbH, Weinheim.

Hannig M., Lavik G., Kuypers M. M. M., Woebken D., MartensHabbena W. and Jurgens K. (2007) Shift from denitrification to anammox after inflow events in the central Baltic Sea. Limnol. Oceanogr. 52, 1336-1345.

Hietanen S. and Kuparinen J. (2008) Seasonal and short-term variation in denitrification and anammox at a coastal station on the Gulf of Finland, Baltic Sea. Hydrobiologia 596, 67-77.

Hietanen S., Jäntti H., Buizert C., Jürgens C., Labrenz M., Voss M. and Kuparinen J. (2012) Hypoxia and nitrogen processing in the Baltic Sea water column. Limnol. Oceanogr. 57, 325-337. http://dx.doi.org/10.4319/1o.2012.57.1.0325.

Hulth S., Aller R. C., Canfield D. E., Dalsgaard T., Engstrom P., Gilbert F., Sundback K. and Thamdrup B. (2005) Nitrogen removal in marine environments: recent findings and future research challenges. Mar. Chem. 94, 125-145.

Jensen M. M., Kuypers M. M. M., Lavik G. and Thamdrup B. (2008) Rates and regulation of anaerobic ammonium oxidation and denitrification in the Black Sea. Limnol. Oceanogr. 53, 23 36.

Jensen M. M., Petersen J., Dalsgaard T. and Thamdrup B. (2009) Pathways, rates, and regulation of $\mathrm{N}_{2}$ production in the chemocline of an anoxic basin, Mariager Fjord, Denmark. Mar. Chem. 113, 102-113. http://dx.doi.org/10.1016/ j.marchem.2009.01.002.

Kristiansen S. and Schaanning M. T. (2002) Denitrification in the water column of an intermittently anoxic fjord. Hydrobiologia 469, 77-86.

Kuypers M. M. M., Lavik G., Woebken D., Schmid M., Fuchs B. M., Amann R., Jørgensen B. B. and Jetten M. S. M. (2005) Massive nitrogen loss from the Benguela upwelling system through anaerobic ammonium oxidation. Proc. Natl. Acad. Sci. U.S.A. 102, 6478-6483.

Lam P. and Kuypers M. M. M. (2011) Microbial nitrogen cycling processes in oxygen minimum zones. Annu. Rev. Mar. Sci. 3, 317-345. http://dx.doi.org/10.1146/annurev-marine-120709142814.

Lam P., Jensen M. M., Lavik G., McGinnis D. F., Muller B., Schubert C. J., Amann R., Thamdrup B. and Kuypers M. M. M. (2007) Linking crenarchaeal and bacterial nitrification to anammox in the Black Sea. Proc. Natl. Acad. Sci. U.S.A. 104, 7104-7109.

Lass H. U., Prandke H. and Liljebladh B. (2003) Dissipation in the Baltic proper during winter stratification. J. Geophys. Res. [Ocean] 108. http://dx.doi.org/10.1029/2002jc001401.

Matthäus W., Nehring D., Feistel R., Nausch G., Mohrholz V. and Lass H. U. (2008) The inflow of highly saline water into the Baltic Sea. In State and Evolution of the Baltic Sea, 1952-2005: a Detailed 50-Year Survey of Meteorology and Climate, Physics, Chemistry, Biology, and Marine Environment (eds. R. Feistel, G. Nausch and N. Wasmund). John Wiley \& Sons, Inc., Hoboken, pp. 265-309.

Millero F. J. (1986) The thermodynamics and kinetics of the hydrogen sulfide system in natural waters. Mar. Chem. 18, 121147.

Naqvi S. W. A., Bange H. W., Farias L., Monteiro P. M. S., Scranton M. I. and Zhang J. (2010) Marine hypoxia/anoxia as a source of $\mathrm{CH}_{4}$ and $\mathrm{N}_{2} \mathrm{O}$. Biogeosciences 7, 2159-2190. http:// dx.doi.org/10.5194/bg-7-2159-2010.

Nausch G., Nehring D. and Ertebjerg G. (1999) Anthropogenic nutrient load of the Baltic Sea. Limnologica 29, 233-241.

Reissmann J. H., Burchard H., Feistel R., Hagen E., Lass H. U., Mohrholz V., Nausch G., Umlauf L. and Wieczorek G. (2009) Vertical mixing in the Baltic Sea and consequences for eutrophication - a review. Prog. Oceanogr. 82, 47-80. http:// dx.doi.org/10.1016/j.pocean.2007.10.004.

Risgaard-Petersen N., Meyer R. L. and Revsbech N. P. (2005) Denitrification and anaerobic ammonium oxidation in sediments: effects of microphytobenthos and $\mathrm{NO}_{3}^{-}$. Aquat. Microb. Ecol. 40, 67-76.

Rönner U. (1983) Distribution, production and consumption of nitrous oxide in the Baltic Sea. Geochim. Cosmochim. Acta 47, 2179-2188.

Rönner U. and Sörensson F. (1985) Denitrification rates in the lowoxygen waters of the stratified Baltic proper. Appl. Environ. Microbiol. 50, 801-806. 
Schönharting B., Rehner R., Metzger J. W., Krauth K. and Rizzi M. (1998) Release of nitrous oxide $\left(\mathrm{N}_{2} \mathrm{O}\right)$ from denitrifying activated sludge caused by $\mathrm{H}_{2} \mathrm{~S}$-containing wastewater: quantification and application of a new mathematical model. Water Sci. Technol. 38, 237-246.

Stockenberg A. and Johnstone R. W. (1997) Benthic denitrification in the Gulf of Bothnia. Estuar. Coast. Shelf Sci. 45, 835-843.

Sørensen J., Tiedje J. M. and Firestone R. B. (1980) Inhibition by sulfide of nitric and nitrous oxide reduction by denitrifying Pseudomonas flourescens. Appl. Environ. Microbiol. 39, 105108.

Tam T.-Y. and Knowles R. (1979) Effects of sulfide and acetylene on nitrous oxide reduction by soil and Pseudomonas aeruginosa. Can. J. Microbiol. 25, 1133-1138.

Thamdrup B. and Dalsgaard T. (2000) The fate of ammonium in anoxic manganese oxide-rich marine sediment. Geochim. Cosmochim. Acta 64, 4157-4164.

Thamdrup B. and Dalsgaard T. (2002) Production of $\mathrm{N}_{2}$ through anaerobic ammonium oxidation coupled to nitrate reduction in marine sediments. Appl. Environ. Microbiol. 68, 1312-1318.

Thamdrup B. and Dalsgaard T. (2008) Nitrogen cycling in sediments. In Microbial Ecology of the Oceans (ed. D. L. Kirchman), 2nd ed. John Wiley \& Sons, Inc., Hoboken, New Jersey, pp. 527-568.

Tuominen L., Heinänen A., Kuparinen J. and Nielsen L. P. (1998) Spatial and temporal variability of denitrification in the sediments of the Northern Baltic Proper. Mar. Ecol. Prog. Ser. 172, 13-24.

Thamdrup B., Dalsgaard T., Jensen M. M., Ulloa O., Farias L. and Escribano R. (2006) Anaerobic ammonium oxidation in the oxygen-deficient waters off northern Chile. Limnol. Oceanogr. 51, 2145-2156.

Ulfsbo A., Hulth S. and Anderson L. G. (2011) pH and biogeochemical processes in the Gotland Basin of the Baltic Sea. Mar. Chem. 127, 20-30. http://dx.doi.org/10.1016/ j.marchem.2011.07.004.

Voss M., Dippner J. W., Humborg C., Hürdler J., Korth F., Neumann T., Schernewski G. and Venohr M. (2011) History and scenarios of future development of Baltic Sea eutrophication. Estuar. Coast. Shelf Sci. 92, 307-322. http://dx.doi.org/ 10.1016/j.ecss.2010.12.037.

Voss M., Emeis K. C., Hille S., Neumann T. and Dippner J. W. (2005) Nitrogen cycle of the Baltic Sea from an isotopic perspective. Global Biogeochem. Cycles 19, GB3001.

Walsh D. A., Zaikova E., Howes C. G., Song Y. C., Wright J. J., Tringe S. G., Tortell P. D. and Hallam S. J. (2009) Metagenome of a versatile chemolithoautotroph from expanding oceanic dead zones. Science 326, 578-582. http://dx.doi.org/10.1126/ science. 1175309 .

Associate editor: David Johnston 